\title{
The Same Term but Different Connotations: Cultural and Historical Perspectives on Studying the Academic Profession in China and Other Asian Countries
}

\begin{abstract}
Through experiencing and reviewing multiple-country endeavors in academic profession study and participating in a new project regarding the academic profession in Asia, the author pinpoints and anticipates the shortcomings of study alone or dominantly questionnaire-based and ignoring the broader social context. The author proposes a new perspective or methodology to mitigate these shortcomings. The traditional approach focuses on commonalities rather than differences of the academic profession in a variety of countries. By comparing identical questionnaires, it is easy to conclude that, according to some indicators, the academic profession in developing countries, a category in which most Asian countries belong, is inferior to that in developed countries by a certain magnitude. This research strategy will devalue the research efforts on the academic profession in Asia. The academic profession is a complicated phenomenon, and it requires a sophisticated research methodology. The characteristics of the academic profession in Asia can be induced by empirically studying its relationship with the institutional environments in which the academic profession is embedded. In addition, all developing countries in Asia are undergoing a process of modernization. This dynamic feature is valuable and deserves exploration. The institutional environments in Asia can be demonstrated and illustrated via cultural and historical lenses.

The purpose of this paper is to review international projects and literature regarding the academic profession. This review tries to be both critical and constructive, and shed light on newly initiated projects in the Asian academic profession. Two major research questions are raised by the author: What is the scholarly value of the new project? What strategy can researchers employ for this endeavor? Past research is dominated by the structure-function paradigm and cross-sectional questionnaire method. This approach has both strengths and weaknesses. Historical and cultural perspectives are proposed to overcome the
\end{abstract}


existing limitations and explore the potential value of the new academic effort.

Keywords academic profession, China, Asia, cultural and historical perspectives

\section{Perspectives on the Study of the Academic Profession in Asia}

The academic profession has been a classic issue in higher education research. Many scholars have explored this topic, and significant knowledge has been accumulated. The academic profession has become an entry in major encyclopedias and handbooks (Enders, 2006; Rhoades, 2007). Surveys have been employed as major tools for carrying out research. A survey of the academic profession in the US was sponsored by the Carnegie Council on Policy Studies in Higher Education in 1969. Since then, two international surveys have been conducted worldwide. One was undertaken by the Carnegie Foundation for the Advancement of Teaching in 1992, involving 14 countries. The other was in 2007, involving 18 countries. The study of the academic profession has until recently mainly focused on developed countries. This point can be illustrated by the bibliography listed in the book The Changing Academic Workplace: Comparative Perspectives edited by Philip G. Altbach (2000). In the 1992 survey, all 14 countries were either middle- or high-income economies. In Asia, Japan, South Korea, and Chinese Hong Kong participated in the project (Altbach, 1996). The exception is the study led by Altbach (2002) that focused on the academic profession in developing countries. In The Decline of the Guru, Altbach highlighted the gap between developed and developing countries and identified the special challenges that the academic profession faced in developing countries; problems and challenges that are real and formidable, if not surprising. Nevertheless, the potential value of studying the academic profession in developing countries is not fully realized if we just focus on problems and difficulties. There are "upsides" as well. For example, the academic profession is highly respected in developing countries, and it can work effectively even given deteriorating conditions.

In the survey conducted in 2007, five of the 18 participating countries were in Asia. In addition to Japan, South Korea, and Chinese Hong Kong that had all participated in the previous survey, Malaysia and the mainland of the People's Republic of China joined the list of participants. For the purpose of cross-country comparison, almost identical questionnaires were employed, and about 24,000 questionnaires were collected. The resulting data is being analyzed, and new publications will come into being. Between 2005 and 2009, several conferences were organized, and publications were made available from the study (RIHE, 
2006; Mogan \& Teichler, 2007; RIHE, 2008). ${ }^{1}$ While not an official member of the team, the author was invited to participate in some activities and gained first-hand experience. From the survey in 1969 to the surveys in 1992 and 2007, a pattern or routine has emerged for the study of the academic profession. It has both strengths and weaknesses. In 2011, a new project entitled The Changing Academic Profession in Asia, was proposed and headed by Hiroshima University, involving several countries in the Asian region. It is the first research initiative focused on the academic profession in Asian countries. At the beginning of the project, it is useful to think about the potential value of this new study. If the research strategy remains the same as before, with the same instrument being employed or adjusted a bit and the only change being a new sample of countries and institutions, the potential value of the study cannot be fully achieved because it cannot tell new things except magnitude difference of measure dimensions. Nevertheless, if we can place the study squarely within the political, economic, social, cultural, and historical contexts of Asian countries, then a distinctively Asian perspective can be developed, and cross-cultural implications can be explored and underscored. Moreover, such a study can be expected to shed light on academic profession worldwide. There is no doubt that the new research strategy can be optimized only by creating an Asian perspective and implementing it effectively.

\section{Thinking Outside the Western Box}

There can be no doubt that developed countries are superior to developing countries in not only their economies but also in higher education development. This leads to a situation in which scholarly theories and methods in developing counties are obviously shaped by those in developed countries. Moreover, higher education study is alienated from other disciplines of social sciences. Taking China for example, as an institutionalized field of study, higher education research emerged in China in the late 1970s and early 1980s. Since then, the university faculty or the academic profession has been an object for higher education research. The specific topics are wide in scope and vary from time to time. They include social roles, turnover, structural profiles (academic degrees, ranks and titles, specialties, gender, ethnicity, and age, etc.), workload and performance, teaching quality, student-faculty relationships, research publications, salary, satisfaction, appointment terms and working conditions. In sum, most Chinese research efforts concentrated on specific problems and tried

\footnotetext{
${ }^{1}$ Also See Diversification of Higher Education and the Academic Profession Papers from the Hercules symposium, Turin, Italy 2009 Supported by the Fondazione Compagnia di San Paolo. European Review. (2010), 18(S1).
} 
to find solutions to the problems. Furthermore, these studies have been conducted without sufficiently referring to the relevant literature and theories in the social sciences, such as sociology of the professions, and have been narrow in perspective. Few studies are based on large-scale surveys. Consequently, no systematic comparison can be made between China and other countries (Zhang \& Shen, 2007).

Chinese Mainland first participated in the international survey of the academic profession in 2007. Professor Shen Hong from Huazhong University of Science and Technology conducted the survey and made related analyses. Her first paper dealt with the academic profession's profile (Shen, 2006), and the second focused on doctoral student education, which supplies candidates to the academic profession (Shen, 2007a). Afterwards, Shen and her students (Shen, 2007b; Gu, 2010) published a few papers and books that included quantitative data. Shen's recent presentation (see Shen, 2012) at Beijing Forum focuses on a cross-country comparison of working time from survey data.

The author was invited to some events of CAP and participated in the 2008 Hiroshima CAP conference, 2009 Turin conference, sponsored by Academia Europaea, and 2011 Wuhan conference organized by Huazhong University of Science and Technology. My first paper (Yan \& Chen, 2008) for the Hiroshima conference dealt with the educational backgrounds and career paths of faculty in higher education institutions in the municipality of Beijing. A specific concept in organizational sociology—danwei ${ }^{2}$ — was employed to help make the data analysis theoretically meaningful. My second paper (Yan, 2010) for the Turin conference placed the academic profession in the context of the government, organization and market "triangle" and tried to depict institutional constraints and dynamics. ${ }^{3}$

Through personal involvement in the activities, the great international efforts on this topic were impressive, but the academic contribution rather disappointing. Based on a review of the literature, the following comments on previous studies can be made. First, there is a concern to be made about theory building, or its absence. Previous investigators paid much attention to data collection and analyses of questionnaire responses, but not enough attention to theoretical interpretation and theory building. So far, the study of the academic profession has been insulated within the narrow confines of higher education research. No serious efforts have been made to learn from, and apply, theories in the social

\footnotetext{
${ }^{2}$ Danwei is a term that intends to express a special connotation of social units that is parallel to "organization" in western countries.

3 The author borrowed the "Triangle" idea from Burton Clark's (1983) work. The triangle framework put the academic profession at the core surrounded by a triangle consisting of government, organizations, and markets. This means that the academic profession can only be studied explicitly by being related to government, university organization, and the market.
} 
sciences, such as modernization theory, social capital theory, institutional theory, theory of the professions, et cetera. Only a few exceptions can be found, such as the analytical quadrant defined by the dimensions of particularism-universalism, and ascription-achievement proposed by Akira Arimoto (2008). He put Japan and the US into the quadrant for traditional/modem comparison. I shall talk about it in more detail in the following section. Furthermore, intellectuals have long been a topic for study in both China and other countries. Historians and sociologists have studied the role and significance of this social group and published many interesting findings. But little reference to this literature on intellectuals has been made in the study of the academic profession.

Second, the methodology employed in previous studies causes concern. An assumption is made in the survey that each individual academic is an independent actor. Therefore, information is collected from each individual about his or her attitude and behavior. No interactions among individuals or beyond-individual-level analyses are taken into account. Due to employing an identical survey instrument, particularities in social context are ignored to a large extent. Concrete behaviors and differences were carefully analyzed, but institutional and social factors were left behind. This strategy might be implicitly appropriate for Western countries which share similar academic institutions, but explicitly inappropriate for developing countries, which are distinct from Western countries in many aspects. Under the circumstances, institutional contexts are prerequisite for interpreting individual behavior differences. Furthermore, all analyses concern the current situation, and historical analyses are largely forgotten. Without taking social context into account, interpretation based on the survey seems to be impossible or superficial or even misleading.

Third, there are concerns about the representativeness of the sample. Large higher education systems are complex and fragmented along divides such as public/private, research/teaching/vocational, and national/local higher education institutions. The academic profession in a complex system with wide differences among institutions of different types and localities and within the same institution among those in difference disciplines. If the sample size is not big enough and not randomly selected, findings based on the small sample might be biased and cannot be generalized to the country level.

In previous projects, sample sizes vary from hundreds to thousands, but they are quite small compared to populations. Moreover, they are not strictly random samples, and the validity and reliability are challenged. For example, the author wonders if respondents can remember and provide accurate data on their income, research funding, publication and working time in the questionnaire. Trivial differences can be found when the Likert scale is employed in the questionnaire. As a result, conclusions based on such an unrepresentative and nonrandom sample are not on a solid ground. 
In sociological terms, the academic profession is embedded in particular social and historical contexts. In order to capture the characteristics of the academic profession, it is necessary to understand the contexts first. Without knowledge about the contexts, it is hard to interpret the data. This is particularly true for the Mainland China, a very diverse and dynamic society.

\section{Special Features of Asian Societies and Their Higher Education Systems}

It is easier to make a judgment of one country's economic development by GDP and quantitative aspects of higher education by enrollment, but one should be cautious to do that for cultural aspects of society in general and higher education in particular. Just as Europe is not only a geographic but also a cultural concept, so too does Asia have both geographic and cultural connotations. In order to study the academic profession in Asia, it is necessary to put it into the contexts of higher education systems and societies. Asia is the continent with the largest land mass, population, and most diverse cultures. There existed three different major cultures in ancient Asia: the Arabic or Islamic religion in West Asia, the Hindu and Buddhist religions which originated in South Asia, and the Confucian culture in East Asia (He, 2010). Prior to the 16th century, the cultures of East Asia were among the most sophisticated and complex in the world in many ways, especially relating to technology, transportation, warfare, and education opportunities. After the 16th century, the center-periphery pattern was reversed due to the progress of Western civilization. In 1492, the Western hemisphere was discovered by Europeans. The Scientific Revolution started in Britain in the 17th century, followed by the Industrial Revolution and the Enlightenment in the 18th century. These significant events helped position Europe at the center of the world. Western civilization spread out worldwide through colonization and broad dissemination of the Western canon. Consequently, Asian cultures were challenged and in many ways threatened by Western cultures.

Modernization is an ongoing process, composed of material, technological, institutional and cultural change. In general, it has a positive impact on human development. However, some problems accompany modernization, such as deterioration of natural and ecological environments, colonization, misuse of scientific and technological inventions, ideological differences and cold war, conflict between cultures, and so forth. In essence, instrumental rationality is overemphasized, and value rationality is underemphasized. Most Asian countries are undergoing modernization. Can Asian countries avoid the problems that often accompany Western-style modernization? Can they maintain and even prosper within their traditional cultures? These are questions that Asian countries have to 
address. Efforts to explore the question can contribute to the general theory of modernization.

All cultures have experienced a great number of evolutions. But their core value systems have been inherited and become underpinnings of current society. Western cultures, Hebrew culture, Islamic culture, Indian cultures, and Chinese culture have all underwent successfully the test of modernization (Yu, 1987). All civilizations cannot only coexist peacefully, but can also be integrated and cross-fertilized. This is quite conducive to the prosperity of human beings. Historically, the Christian religion benefited from Greek philosophy, and Confucian culture benefited from Buddhism. We hope that Asia can, again, contribute to the civilizations of the world. In the 1990s, former Prime Minister of Singapore Lee Kuan Yew and former Prime Minister of Malaysia Datuk Seri Mahathir Bin Mohamad proposed the key elements of "Asian" values. In their words, Asian people value collectivity, social harmony, family ties, respect for authority, and emphasize discipline and social order (Li, 2010). From a research standpoint, the proposition needs to be approved or disapproved empirically.

Is East Asian culture a facilitator or an obstacle to East Asian economic development? Rigorous research does not lead to an absolute or simple conclusion. Different assessments have been advanced from different theoretical schools and at different times. In the 1980s, while the economies of Japan and the "Four Small Dragons" (Singapore, South Korea, Hong Kong, and Taiwan) grew rapidly, their dynamism was often attributed to East Asian culture. But when the financial crisis occurred in East Asia in 1997, its culture was blamed as a possible impetus that led up to the regional financial crisis (Ruan, 2010). In China, there are two competing schools of thought which interpret the economic progress of East Asia differently. The first school is market success or comparative advantage in the market system, which interprets Asian economic success as the result of its comparative advantage in labor supply and costs. The second school is the so-called new-left, and attributes Asian economic success to "planning rationality" through strong government intervention (Zheng, 2004). The above is just one example of cultural and institutional interpretation in the study of economics. Researchers on the academic profession should know arguments in neighboring disciplines.

By the same principle, there are two competing theories of modernization. The first theory assumes that modernization will lead the world to congruence, with the US as the prototype that the world can follow. The second theory assumes that the world will maintain its heterogeneity, and there will be various paths to modernization ( $\mathrm{Tu}, 2004)$. Cultural diversity is thought as a prerequisite for world prosperity (Hayhoe, 2003). King (2002, p. 232) pointed out that globalization had arisen in the West to rediscover the particularity, locality, difference, and review of modernity. If we only look at the 20th century, we 
might conclude that the theory of congruency is supported. But if we consider the long history of human development, we cannot deny that Eastern Civilization has made great contributions to the whole world. To name a few, India contributed to mathematics, Arabs played a crucial role in the inheritance of Greek civilization, and China made "Four Great Inventions," papermaking, the compass, gunpowder, and movable type printing, that have had a great impact on the development of the world's civilization. In prospect, it is estimated by some that the biggest threat to the world in the 21 st century is not economic and political but religious based (e.g., the potential conflict between Christianity and Islam). Therefore, mutual respect and dialogue between cultures are quite necessary. Scholars in developing countries are thus challenged to address the crucial practical and theoretical issues. Higher education researchers need to realize these academic debates and are recommended to link academic profession study with scholarly development in social sciences.

Almost every country has its own history of scholarship. However, the modern higher education system is a relatively new worldwide phenomenon. It originated in Europe in the Middle Ages, and no country had maintained its own higher education system prior to that epoch (Altbach \& Umakoshi, 2004). The formation of the academic profession, as a part of higher education development, also resulted from modernization. No doubt, differences exist in the academic profession between West and East. Will the differences disappear or persist? As congruent or diverse arguments for modernization, one model or multiple models are arguably hypothesized for modernization of the academic profession. Asian countries have to face the dilemma that they have found it necessary to borrow Western theories to interpret indigenous practices. Under the circumstances, this can lead to idiosyncratic interpretation of indigenous innovation and ignore universal implications of indigenous practices, and even evaluate indigenous practices by Western theories, for example, unidentified property rights promoted the development of village and township enterprises in China. This is difficult to explain by the Western theory of property rights. The point is that we need to pay attention to particular scenarios in Asian academic profession and be involved in theoretical dialogue or even develop new theory to interpret them.

In sum, the author advocates an Asian perspective be developed for the study of the "Asian" academic profession. In doing so, particularities should first be observed and studied by comparing the Asian countries with the rest of the world. Second, these particularities should not be dismissed casually, and efforts should be made to interpret them. Finally, new theory might be fostered by developing the capacity through the understanding and development of analytical models. Of course, a concrete Asian perspective cannot be developed in a rushed or haphazard manner. But from the author's point of view, the Asian perspective should take at least modernization and culture into consideration. 


\section{Different Interpretations of China's Economic Success}

When we talk about Asian modernization, China is a special case with rapid economic growth and dramatic social changes that have caught worldwide attention. In what aspects does China differ from the rest of world? In ancient China, the concept of the nation-state did not exist. Instead, the concept of heaven circumscribed the boundary of Confucian culture, which spanned several countries in East Asia, including Vietnam and South Korea. The name of China_zhong guo-means the center of the world. Thus, China has a long history of self-confidence in its cultural superiority. This situation was altered in the 16th century when powerful Western cultures brought by missionaries met with Chinese culture. In the middle of the 19th century, Chinese culture lost its superiority to Western culture in the Opium War. Prior to 1978, when China adopted its reforms and "opening up" policy, she had gone through five modernization movements. Listed in chronological order, they are the Westernization Movement, Constitution Reform and Modernization, the Revolution of 1911, the New Culture Movement, and the Cultural Revolution respectively (King, 2010, pp. 36-38). Similar to modernization in other nations, China's modernization has included the following transformations: from agricultural economy to industrial economy, from rural community to modern society, and from ascription to achievement (King, 2010, pp. 61-62). ${ }^{4}$

Nevertheless, China differs from other countries in its cultural components and evolution. Culture is an ideal-type abstraction of the general characteristics of a particular country. It is also a historical construct, closely related to the tradition and evolving into the future. Cultural comparisons have been drawn between the US and China as follows (King, 2010, p. 103): US culture is defined by capitalism, core or "nuclear" family, individualism, right (vs. obligation or responsibility) orientation, democratic political system, and an emphasis on science and technology. China's culture, by contrast, is defined by an agricultural economy, familism, an obligation orientation, ancestor worship, and the art of human relations. In brief, fundamental characteristics of Chinese culture are art and ethics, and those of Western culture are philosophy and science (King, 2010, p. 120). The comparison does not deny that China shares similarities with other countries.

China had gone through uneven progress since Deng Xiaoping's leadership in 1978. Since then, China has entered a new epoch. It reformed her economic, political, and social systems in a systematic way and made great progress toward

\footnotetext{
4 "Community" refers to simple ties in villages, and "society" refers to complex ties in cities. "Ascription" refers to status related to family backgrounds, and "achievement" refers to personal education, skills, efforts, and productivity.
} 
modernization. The continuous 30-year economic growth allowed the Chinese to recapture their cultural self-confidence. Nowadays, the Chinese model and experience have become buzz words (Zheng, 2010; Pan \& Ma, 2010; Ding, 2011). To what can one attribute China's economic success? Two competing theories are available (Chen, 2010; Zheng, 2004). Neo-classic economists attribute it to the adoption of the free market system. Further development is suggested to deepen reform and establish an even freer market and legal system. By contrast, new leftists attribute it to Mao's legacy. A strong and centralized government has helped China to achieve rapid growth and overcome financial crises effectively. How should China deal with international trade rules? The new leftists argue that existing rules are created by Western nations, and they do not necessarily accrue to China's benefit. On the contrary, neo-classic economists argue that China must abide by international and universal rules for its wellbeing (Zheng, 2004, p. 182). The debate is hot in China's social sciences, and scholars studying the academic profession can learn and benefit from the fundamental questions raised by other disciplines.

In sum, China's modernization shares some similarities with other countries but has its own particularities. If we can study these phenomena objectively and try to interpret them theoretically, contributions can be made to both practice and theory. By the same token, we are challenged by what perspective we should employ to interpret the academic profession phenomenon in China.

\section{Characteristics of China's Academic System and Academic Profession}

In the following section, the unique historical legacy of China's academic and profession will be summarized by way of a literature review of scholarship currently ignored in the mainstream study of the academic profession. Universities are more influenced by history than other types of organizations (Altbach \& Umakoshi, 2004). Thus, Chinese universities will inherit its tradition, learn from international experiences and integrate them with local practices. Particularities in China's academic system and academic profession cannot be well identified without historical accounts. In the book titled Portraits of 21st Century Chinese Universities: In the Move to Mass Higher Education, Ruth Hayhoe and coauthors summarized some unique aspects of Chinese higher education. They pointed out that Chinese higher education is not simply the transplantation of a Western system, but is actually an integration of the Western system with Chinese culture. The cultural core is the key to interpret Chinese particularities. This is also a good proposition for the study of the academic profession in China. In another book-China's Universities: 1895-1995- 
Hayhoe (2000) demonstrated from historical and cultural perspectives that Chinese higher education differs from its Western counterparts in both formality and content: it valorizes integration of knowledge and practice, no division between scholar and government official, epistemology on the basis of practice, and a holistic view of knowledge.

Shidafu is the term for a special social class in ancient China, who had both scholar and government official statuses. It has no exact counterpart in English-speaking countries. But its close English translation is scholar-official, scholar-bureaucrat, or literati and officialdom. In Western societies, scholar and official are separated from each other and categorized into different social statuses. Therefore, shidafu is a special phenomenon unique to ancient China (Yan, 2005).

There are many literatures that compare Chinese scholars with Western scholars. Two types of scholars can be identified in the West: those who interpret the world, and those who change the world. The former was typical in ancient times, and the latter is a more recent phenomenon. We can observe the historical legacy in the contemporary West. By contrast, ancient Chinese scholars were characterized with inward transcendence of dao (doctrine) (Yu, 2005). The purpose of scholarship was human or ethical in ancient China, and it was for the sake of knowledge per se in the West (King, 2010, p. 125). The spiritual orientation of Chinese culture prioritized ethics over knowledge (Xu, 2005). Traditionally, Chinese intellectuals took human spirituality (ethics, human relationships) as the core value, but did not have religious beliefs in God and scientific spiritualities (logical speculation on the principles governing the "objective" world) (Qian, 2005).

The above descriptions are of ancient China. Has the tradition disappeared in the course of modernization? Or has it persisted in an apparent or hidden form? How is Chinese tradition integrated with Western influence and how do they jointly shape the current academic profession in China? Addressing these questions can add value to the study of the academic profession in China. In recent decades, little originality has been demonstrated in the study of Chinese social phenomena. In most cases, theories are borrowed from the West for the interpretation of Chinese phenomena. But as early as the 1920s and 1930s, a Chinese school of sociology was created by Chinese scholars, whose experience shed light on today's study. Chinese sociologist Wu Wenzao and his colleagues undertook in-depth field work and tested Western sociological theories empirically and sharply against Chinese data. This work has created intriguing concepts and contributed to sociological theory ( $\mathrm{Li}, 2008)$. Fei Xiaotong is another past Chinese sociologist who contributed to sociology as a discipline. In his book Earthbound China, Fei (1998) compared Chinese society with Western societies and identified some intriguing comparisons. For example, traditional 
China is a non-litigation oriented society; by contrast, the West is a legally-oriented society. Traditional China is a society emphasizing status; by contrast, the West is a society emphasizing legal contracts. In his later work, Fei reiterated the importance of cultural self-consciousness.

\section{Some Considerations for the Study of the Academic Profession in China}

Because the author's background does not allow for commentary on the Asian academic profession, this section offers ideas on the project of China's academic profession. First of all, the history of academic profession deserves rigorous study. Here follows a brief historical description of China's academic system and academic profession. The modernization of Chinese higher education began in the late 19th century. In 1905, China abolished its Imperial Examination System $\left(k e j u^{5}\right)$ and the Academy $\left(\right.$ shuyuan $\left.{ }^{6}\right)$ system, and adopted a school system from the West. As a result, the social foundation for shidafu collapsed, and the academic profession in the modem sense emerged. Between 1949 and 1978 especially from 1966 to 1976, traditional Chinese culture was completely forsaken, and political intervention exerted a powerful impact on the academic profession. At that time, the social status of the academic profession was inferior to the working class (e.g., workers, peasants, and soldiers). Political correctness was more emphasized than professional competency. In 1952, China adopted the former Soviet Union's higher education model, and the academic profession became overspecialized and practically-oriented. Since 1978, China has gradually adopted a market system. Market forces penetrate the academic profession, for better or worse. Beginning at the end of the last century, two remarkable trends have appeared in China's higher education. The first one is expansion and massification of higher education, a trend which will continue in the coming decades. The second one is the world-class university project (985 and 211 Projects). These two changes are basic contexts for the study of the academic profession in China. These projects have already and will continue to shape the academic profession in both quantity and quality well into the future.

Over the past decade, China's higher education and its academic profession have made great changes. But higher education is more difficult to evaluate than the economy. It seems that some foreign scholars tend to evaluate Chinese higher education more positively, but many Chinese scholars more negatively. As mentioned before, we need to develop a distinctively "Chinese perspective" for

\footnotetext{
${ }^{5} \mathrm{Keju}$ was an examination system by which feudal imperials chose government officials from C.E. 605 to 1905 .

${ }^{6}$ Shuyuan was a non-governmental academy which existed from the Tang Dynasty to the late Qing Dynasty and became full-fledged in the Song Dynasty.
} 
the study of the Chinese academic profession. This perspective needs to take modernization and Chinese culture into account.

Based on modernization theory, the author proposes the following arguments and proposals for the project of the academic profession in Asia in general and China in particular.

First, in his paper, Arimoto (2008) proposed the following quadrants defined by two dimensions: particularism-universalism, on the one hand, and ascription-achievement, on the other (see Fig. 1). This is a useful tool that we can employ for empirical study. We can test whether and the extent to which the Chinese academic profession has moved from tradition to modernization. What are the characteristics of the transition process and why? How does guanxi ${ }^{7}$ (relation) culture or other social customs influence the academic profession's modernization? What are similarities and differences between Chinese guanxi and social capital theory?

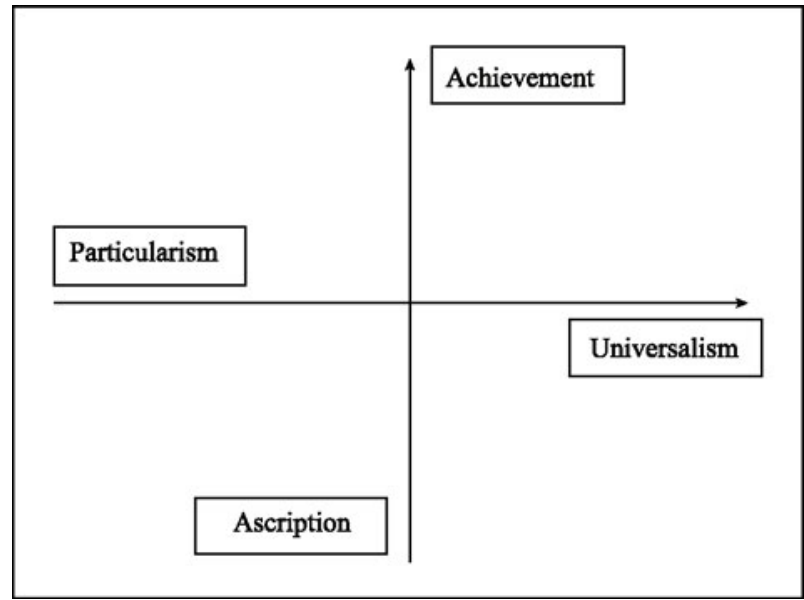

Fig. 1 The Shift from Ascription to Achievement, and from Particularism to Universalism Characterizing Modernization

Source: Arimoto (2008, p.16).

Second, modernization has three components: materials and technology, institutions, and culture. When a country moves from its traditional to its modern stage, comparatively speaking, materials and technology are most easily advanced, culture is most difficult to advance, and institutions are in generally somewhere between. Consequently, the phenomenon of cultural lag can often be seen (King, 2010). Because the Chinese academic profession is going through modernization, there is assumed to be a cultural lag. Corruption is a typical

${ }^{7}$ Guanxi refers to an informal tie in Chinese social contexts. 
example of cultural lag. This is shown that hardware is more developed in the academic system, but software including rules and norms is relatively underdeveloped. Corruption is a typical example of cultural lag.

Third, while a country is moving from its traditional stage to a modern stage, three phenomena will inevitably occur: heterogeneity, formalism, and overlapping (King, 2010, pp. 71-75). Heterogeneity implies that multiple types of academic profession coexist, and disparities are wide-ranging and apparent. Formalism implies that norms are evolving, and existing rules cannot be easily enforced. Overlapping implies that there is no clear-cut division between administration and academic work. We can find many phenomena that are consistent with these hypotheses, such as huge disparities in salary, academic misconduct, bureaucratization of academic work, et cetera. Based on above considerations, specific empirical hypotheses can be developed for the study of academic profession in China. For testing the hypotheses, surveys should be combined with such methods as historical analysis, institutional analysis, and case studies, to name a few.

In summary, at the outset of this paper, the author raised the question: What approaches or strategies are of special value for research on the academic profession in Asia or China? Based on the limitations of previous, mostly Western-oriented research projects, and the cultural distinctiveness and traditions of Asia in general, and China in particular, identification and assumption of a distinctively Asian and Chinese perspective are proposed for the new research initiative entitled Changing the Academic Profession in Asia. The perspective can be developed by taking into account modernization and cultural components. Specific hypotheses can be deduced from theories, such as modernization theory. More importantly, particularities can be highlighted, and theoretical implications can be drawn. To achieve this objective, multiple methods, instead of only a questionnaire approach, must be employed. By doing so, the study of the Asian academic profession is expected to make a unique contribution to the relevant knowledge base of the global academic profession.

\section{References}

Altbach, P. G. (1996). The academic profession in international perspective. In P. G. Altbach (Ed.), The international academic profession: Portraits of fourteen countries and regions (pp. 3-50). Princeton, NJ: The Carnegie Foundation for the Advancement of Teaching.

Altbach, P. G. (Ed.). (2000). The changing academic workplace: Comparative perspectives. Boston, MA: Center for International Higher Education, Lynch School of Education, Boston College.

Altbach, P. G. (2002). Centers and peripheries in the academic profession: The special challenges of developing countries. In P. G. Altbach (Ed.), The decline of the guru: The academic profession in developing and middle-income countries (pp. 1-22). Boston, MA: 
Center for International Higher Education, Lynch School of Education, Boston College.

Altbach, P. G., \& Umakoshi, T. (Eds.). (2004). Asian universities: Historical perspectives and contemporary challenges. Baltimore, MD: The Johns Hopkins University Press.

Arimoto, A. (2008). International implications of the changing academic profession in Japan. In RIHE (Ed.), The changing academic profession in international comparative and quantitative perspectives: Report of International Conference on the Changing Academic Profession Project (pp. 1-31). Higashi-Hiroshima, Japan: Hiroshima University.

Chen, Z. (2010). 陈志武说中国经济 [Chen Zhiwu's comments on China's economy]. 太原, 中国: 山西经济出版社 [Taiyuan, China: Shanxi Economic Press].

Clark, B. (1983). The higher education system: Academic organization in cross-national perspective. Berkeley, CA: University of California Press.

Ding, X. (2011). 辩论 “中国模式” [Debating “Chinese model”]. 北京, 中国: 社会科学文 献出版社 [Beijing, China: Social Sciences Academic Press].

Enders, J. (2006). The academic profession. In J. Forest \& P. G. Altbach (Eds.), International handbook of higher education (pp. 5-21). Dordrecht, Netherlands: Springer.

Fei，X. T. (1998). 乡土中国：生育制度 [Earthbound China: The institutions for reproduction]. 北京, 中国: 北京大学出版社 [Beijing, China: Peking University Press].

Gu, Z. Y. (2010). 我国学术职业流动影响因素的实证研究: 基于 “学术职业的变革-中国 大陆” 问卷调查 [Empirical analyses of influencing factors for academic profession mobility in China: Reforms to the academic profession. 清华大学教育研究 [Tsinghua Journal of Education], 31(3), 73-79. doi: 10.3969/j.issn.1001-4519.2010.03.011

Hayhoe, R. (2000). 中国大学：1895-1995一个文化冲突的世纪 [China's universities: 1895-1995: A century of cultural conflict]. 北京, 中国: 教育科学出版社 [Beijing, China: Educational Science Publishing House].

Hayhoe, R. (2003). In R. Hayhoe \& J. Pan (Eds.) 东西方文化交流与高等教育 [Knowledge across cultures: A contribution to dialogue among civilizations] (pp. 21-22). 南京, 中国: 南京师范大学出版社 [Nanjing, China: Nanjing Normal University Press].

He, S. (2010). 东亚文化价值的历史探索 [Historical exploration of culture and value in Eastern Asia]. In Z. P. Wu \& Y. Li (Eds.), 东亚的价值 [Value of East Asia] (pp. 33-61). 北京，中国: 北京大学出版社 [Beijing, China: Peking University Press].

King, A. Y. C. (2002). 金耀基自选集 [Self-selection of King, Ambrose Y. C.]. 上海，中国: 上海教育出版社 [Shanghai, China: Shanghai Education Press].

King, A. Y. C. (2010). 从传统到现代 [From tradition to modernization]. 北京, 中国: 法律 出版社 [Beijing, China: Law Press].

Li，P. (2008). 20世纪早期社会学中的中国学派 [Chinese school of sociology in early of 20th century]. 社会科学前沿 [Advances in Social Sciences], 12, 203-210.

Li，W. (2010). 构建东亚认同的意义与方法 [Significance and approaches of constructing Eastern Asia identity]. In Z. P. Wu \& Y. Li (Eds.), 东亚的价值 [Value of East Asia ] (pp. 62-77). 北京, 中国: 北京大学出版社 [Beijing, China: Peking University Press].

Pan, W., \& Ma, Y. (Eds.) (2010). 共和国六十年与中国模式 [Sixty years of the Republic and Chinese model]. 北京, 中国: 三联书店出版社 [Beijing, China: Sanlian Shudian].

Qian, M. (2005). 中国知识分子 [Chinese intellectuals]. In J. Xu (Ed.), 20世纪中国知识分 子史论 [History of intellectuals in the 20th century]. 北京, 中国: 新星出版社 [Beijing, China: Xinxing Press].

Rhoades, G. (2007). The study of the academic profession. In P. J. Glunport (Ed.), Sociology of higher education: Contributions and their contexts (pp. 113-146). Baltimore, MD: The 
Johns Hopkins University Press.

Ruan, Q. (2010). 东亚价值与东亚社群思想 [East Asian value and idea of East Asia community]. In Z. P. Wu \& Y. Li (Eds.), 东亚的价值 [Value of East Asia] (pp. 78-88). 北京, 中国: 北京大学出版社 [Beijing, China: Peking University Press].

Shen, H. (2006). Academic profession in China: With a focus on the higher education system. In RIHE. (Ed.), Reports of changing academic profession project workshop on quality, relevance, and governance in the changing academia: International perspective (pp. 79-96). Higashi-Hiroshima, Japan: Hiroshima University.

Shen, H. (2007a). Challenges on the academic profession development by the changing doctoral education in China. In M. Kogan \& U. Teichler (Eds.), Key challenges to the academic profession (pp. 125-144). Paris, France: UNESCO Forum on Higher Education Research and Knowledge \& Kassel, Germany: INCHER.

Shen, H. (2007b). 变革中的学术职业: 从14国/地区到 21 国的合作研究 [Changing academic profession: From fourteen countries and regions to twenty-one countries]. 大学: 研究与评价 [University: Research and Review], 1, 51-55.

Shen, H. (2012). 18国学术职业工作时间的比较分析 [Comparative analysis of working time for 18 countries]. 2012年北京论坛会议论文 [Conference paper for Beijing Forum, 2012].

Tu, W. M. (2004). 全球化与多样性 [Globalization and diversity]. In Harvard-Yenching Institute. (Ed.), 全球化与文明对话 [Globalization and dialogue of civilization] (pp. 75-104). 南京, 中国: 江苏教育出版社 [Nanjing, China: Jiangsu Educational Press].

$\mathrm{Xu}, \mathrm{F}$. (2005). 中国知识分子的历史特性与命运 [Historical character and fortune of Chinese intellectuals]. In J. Xu (Ed.), 20世纪中国知识分子史论 [History of intellectuals in the 20th century] (pp. 63-75). 北京, 中国: 新星出版社 [Beijing, China: Xinxing Press].

Yan, B. (2005). 论士大夫的双重角色 [On the dual roles of “Shi Da Fu”]. In J. Xu (Ed.), 20 世纪中国知识分子史论 [History of intellectuals in the 20th century]. 北京, 中国: 新星 出版社 [Beijing, China: Xinxing Press].

Yan, F. Q. (2010). The academic profession in China in the context of social transition: An institutional perspective. European Review, 18(S1), 99-116. doi: 10.1017/ S1062798709990342

Yan, F. Q., \& Chen, Y. (2008). Analyses of educational backgrounds and the career paths of faculty in higher education institutions in Beijing municipality, China. In RIHE (Ed.), The changing academic profession in international comparative and quantitative perspectives: Report of International Conference on the Changing Academic Profession Project (pp. 265-292). Higashi-Hiroshima, Japan: Hiroshima University.

Yu, Y. (1987). 中国文化的价值及其现代含义 [Modern implication of the value of Chinese culture]. 文化: 中国与世界 [Culture: China and the World ], 1, 62-89.

$\mathrm{Yu}, \mathrm{Y}$. (2005). 中国知识分子的历史考察 [Historical exploration of Chinese intellectuals]. In J. Xu (Ed.), 20世纪中国知识分子史论 [History of intellectuals in the 20th century] (pp. 13-30). 北京, 中国: 新星出版社 [Beijing, China: Xinxing Press].

Zhang, Y., \& Shen, H. (2007). 学术职业: 国内研究进展与文献述评 [The study of the academic profession in China: Literature review]. 大学: 研究与评价 [University: Research and Review], 1, 54-59.

Zheng, Y. (2004). Globalization and state transformation in China. Cambridge, England: Cambridge University Press.

Zheng, Y. (2010). 中国模式: 经验与困局 [The Chinese model: Experience and dilemma]. 杭州，中国: 浙江联合出版集团 [Hangzhou, China: Zhejiang United Publishing Group]. 